\title{
Mass Grave Localization Prediction with Geographical Information Systems in Guatemala and Future Impacts
}

Perla Santillan

Virginia Commonwealth University

Follow this and additional works at: https://scholarscompass.vcu.edu/frsc_projects

Part of the Applied Statistics Commons, and the Other Anthropology Commons

(c) The Author(s)

\section{Downloaded from}

https://scholarscompass.vcu.edu/frsc_projects/15

This Directed Research Project is brought to you for free and open access by the Dept. of Forensic Science at VCU Scholars Compass. It has been accepted for inclusion in Master of Science in Forensic Science Directed Research Projects by an authorized administrator of VCU Scholars Compass. For more information, please contact libcompass@vcu.edu. 
CPerla Santillan

2020

All Rights Reserved 
Mass Grave Localization Prediction with Geographical Information Systems in Guatemala and Future Impacts

A thesis submitted in partial fulfillment of the requirements for the degree of Master of Science in Forensic Science at Virginia Commonwealth University.

By

Perla Santillán

B.A. Biological Anthropology

University of Texas at Austin, May 2013

Host laboratory: Amnesty international

Research Mentor: Tal Simmons, PhD, D-ABFA, Cert FA-I, VCU Department of Forensic Science Committee: Scott Edwards, PhD, Senior Advisor, Crisis Response Team- Amnesty International Jenise Swall, PhD Associate Professor, VCU Department of Statistics and Operations Research

\section{Virginia Commonwealth University}

Richmond, Virginia

Spring 2020

May 2020 


\section{Acknowledgment}

The author would like to thank several people allowed the success of this project.

First, I would like to thank my family, Madre thank you for your unconditional support in the pursue of my dreams. Gracias Madre! Brother, thank you for being an example to follow and being my big brother. Thank you, Max, for being my sounding board and helping me stay sane and fed during this process. Secondly, I would like to thank my mentor and committee members. Dr. Simmons, thank you for giving me the opportunity to work on a project that is a bit out of the box for forensic science and with so much significance to me. Dr. Swall, I appreciate all of your words of encouragement and for reminding me that it is better to try than not. Amnesty International and Dr. Edwards, thank you for supporting this idea and especially thank you, Micah, for providing me guidance during the learning process of the program. Lastly, thank you everyone

who has ever believed in me and thank you for giving me words of encouragement for following my dreams. 


\begin{abstract}
Conducting physical searches for mass grave locations based on anecdotal evidence is a time consuming and resource intensive endeavor in circumstances that often pose a threat to personal safety. The development of tools and procedures to speed such searches can greatly reduce the risk involved, increase the number of individuals whose remains are recovered and identified; and, more importantly, reunite these remains with their loved ones to provide them with a proper burial. Geographic information systems (GIS) software, which can analyze and manipulate the spatial characteristics of known mass grave data, represents a powerful tool that can be used to predict new mass grave locations and increase the speed and efficiency with which they are investigated. Using the open source QGIS project, existing mass grave locations in Guatemala were analyzed based on their distance from and change in elevation relative to roads, streets, waterways, points of interest, and possible villages/towns. Statistical analyses performed to detect relationships among the variables resulted in patterns that warrant further study and can be used to further narrow areas of investigation.
\end{abstract}

Keywords: Mass Graves, QGIS, Humanitarian, Guatemala, Forensic Science, Anthropology.

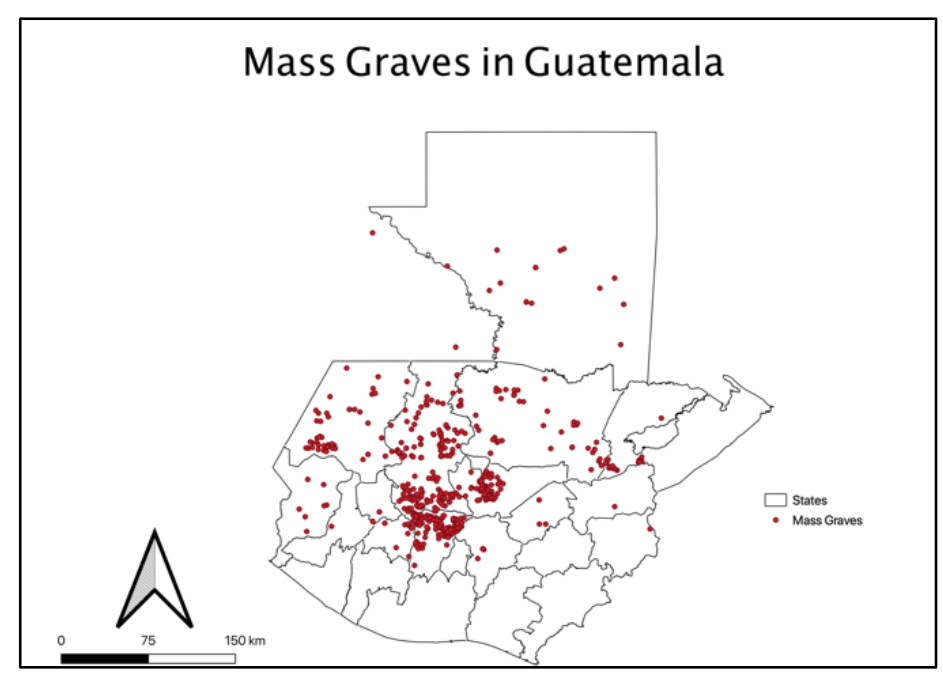




\section{Introduction}

Throughout history, social disturbances, conflicts, wars, famines, and natural disasters have led to countless fatalities (1) around the world. For perceived public health and safety reasons in some instances, the fatalities must be buried rapidly in mass graves without documentation or ceremonial burial. In other instances, mass graves may be used by the perpetrators of crimes in order to conceal evidence (2-4). The families of these victims may not even know their relatives are deceased and may still consider them missing persons. If known to be deceased, the families have nonetheless been denied the opportunity for their customary mortuary rituals, closure, and receipt of death certificates, which are necessary in order to move forward with many legal matters.

After an armed conflict has ended, it is fundamental for the community's reconciliation to identify the location of mass graves and repatriate bodies to their loved ones for customary burial practices. Furthermore, mass graves can also hold critical information about the events surrounding the deaths, such as numbers of deceased, postmortem biological profile data concerning the identification of the deceased, as well as forensic evidence that may assist in achieving transitional justice (5-9).

In Guatemala in the early 1960's, an armed conflict that lasted until the mid-1990's occurred between the government and its repressed indigenous population (10). During the armed conflict, many indigenous peoples and opposers of the government were killed, and their bodies frequently disposed of in mass graves. At times, the bodies were left in place to induce fear, and communities had to bury their own dead in mass graves before fleeing from persecution; thus, 
often times no documentation other than personal accounts for the location of burial has survived (11). According to Guatemala's Commission for Historical Clarification (Comisión para el Esclarecimiento Histórico, $\mathrm{CEH}$ ), the long-lasting armed conflict, now known as the Guatemalan Civil War, resulted in more than 200,000 victims. Out of these victims, the CEH estimates that 42,275 individuals were executed or forcibly disappeared, with many of them interred in unmarked clandestine mass graves (12).

Organizations such as the Argentine Forensic Anthropological Foundation (EAAE), the Forensic Anthropology Foundation of Guatemala (FAFG), Amnesty International, and the International Committee of the Red Cross and Red Crescent (ICRC), work to locate mass graves. EAAF and FAFG and other organizations exhume graves and then work to reunify the remains of individuals with their families (13-16). Traditionally, the location of mass graves has been done in the field using personal accounts of survivors and extensive searches, which provide information concerning a few locations to further investigate (17); only a few of these yield success in terms of actually discovering graves. The use of technology to try to predict locations based on taphonomy spectral reflectance $(18)$, geoscience $(19,20)$, soil disturbances from decomposition of bodies and vegetation (21), and different decomposition environments (22), among others, has also been employed occasionally and with varying success. In recent years, studies have focused on spatial analysis to create predictive and deductive models for the location of clandestine graves (23-27).

The FAFG was created for the investigation and documentation of human rights violations and murders that occurred during Guatemala's Civil War (14). Since it was founded, the organization's recovery efforts have been highly successful; they have been able to collect personal 
accounts that have led to the identification of mass graves, and ultimately to the repatriation of more than 5,000 individuals. However, less than $10 \%$ of the bodies of the fatalities predicted by the $\mathrm{CEH}$ have been recovered (Table 1). Further complicating the recovery efforts, locations of exhumed mass graves are not in a clustered area, but spread throughout the country (Figure 1). In addition, the volume of remains in mass graves can range in magnitude from one individual to dozens, thus making it a challenge to identify the location of the remaining graves by specific common features (Figure 2).

The next step to assist in the recovery, identification, and repatriation of the missing would be to build a tool that will allow organizations such as Amnesty International and others, e.g. FAFG within Guatemala, to rapidly localize the potential sites of these mass graves. The purpose of this study was to explore and analyze the existing data collected by FAFG from their previously published investigations in Guatemala (14) in order to examine patterns using QGIS (28) and algorithms within the system to help reduce locations to be searched. This research attempted to determine if predicting the location of mass graves is possible and, if so, whether it is possible to determine how many individuals are in the predicted graves. To ensure the methodology would be available to anyone interested in the outcome, this project utilized open data sources and programs to acquire information, and widely known analytical processes. Additionally, this research will create a pathway for future research aimed at creating a more generalized model for the prediction of mass grave locations in Guatemala and other countries. 


\section{Data and Methods}

Features investigated in this research include roads, streets, waterways, points of interest, and administrative boundaries. These were chosen based on their availability in an open source format as well as their worldwide presence, which will allow this research to be replicated in other countries.

\section{Data Acquisition}

The Mass Graves data set used in this study contained information on a total of 1274 mass graves investigated in Guatemala by the FAFG. It was derived from FAFG's website containing investigation reports and exported to a comma separated value (CSV) file. Information contained in these reports included location in latitude and longitude, total number of individuals recovered, date of exhumation, and presumptive date of burial. Each mass grave was given a unique identifier and $75 \%$ of the total 1274 mass graves were selected at random using an excel algorithm in order to arrive at the 954 mass graves that were used to move forward with the analyses.

Data sets containing the roads, streets, waterways, points of interest, and administrative boundaries (country, state, municipality) were sourced from the Humanitarian Data Exchange in Shapefile format. The OpenStreetMap project was the original source for the roads, streets, waterways, and points of interest data.

The Digital Elevation map data was sourced from the US Geological Survey Earth Explorer program in raster format with 1 arc second resolution from the year 2000 Shuttle Radar Topography mission. 


\section{Data Processing}

The mass graves dataset was converted to a shapefile using the QGIS add tabular data tool. The Digital Elevation Map was added as a raster layer. Roads, streets, waterways, points of interest, and administrative boundaries data were added as vector layers.

To evaluate the geographical characteristics of mass grave locations, it was necessary to process the data by performing transformations and analyses of the base datasets to evaluate mass grave distance from and change in elevation between key features.

Distance from Mass Graves to Roads, Streets, and Waterways

Using the GRASS algorithm v.to.points, each layer was converted from lines to points. For the Waterway layer, the conversion from lines to points excluded polygons representing lakes or large bodies of water. Using the Field Calculator function rownum, each point was assigned a unique identification number. The QGIS distance to nearest hub (line to hub) algorithm was then used to identify the point nearest to each mass grave, calculate the distance between them in meters, and generate layers containing line features connecting the respective points to the nearest mass grave. These layers were joined to the Mass Graves layer using the unique ID for each mass grave and then using the Field Calculator, the distance fields were added to the mass grave dataset as RdDist, StDist, and WWLDist. 
Distance from Mass Graves to Possible Towns

A preexisting layer for Guatemalan towns could not be located. Based on the assumption that tightly grouped street patterns represented outlying towns or villages in rural areas, possible towns were identified using QGIS DBSCAN clustering of street line features no more than .005 degrees apart with a minimum cluster size of 5 features. This generated a new street line layer with a cluster ID field. The minimum bounding geometry algorithm using a convex hull function and cluster ID as a grouping variable was used to generate polygons representing the boundaries of each possible town. Then the SAGA polygon centroids algorithm was used to create a point layer representing the center point for each possible town. The QGIS distance to nearest hub (line to hub) algorithm was then used to identify the point nearest to each mass grave, calculate the distance between them in meters, and generate a layer containing line features connecting the respective points to the nearest mass grave. This layer was then joined to the Mass Graves layer using the unique ID for each mass grave and then using the Field Calculator, the distance field was added to the mass grave dataset as PosTwnDst.

Distance from Mass Graves to Selected Points of Interest

Determining the location of points of interest was necessary for this research, since many accounts state that some mass killings happened in town centers or plazas, or that victims were gathered in a specific place in a town (30). The Points of Interest layer was filtered to include only community centers, hospitals, places of worship, schools, and town halls. These features are the most likely places representative of a community, others such as supermarkets, apartments and businesses may only be representative of larger communities or cities. The QGIS distance to nearest hub (line to hub) algorithm was then used to identify the point nearest to each mass grave, 
calculate the distance between them in meters, and generate a layer containing line features connecting the respective points to the nearest mass grave. This layer was then joined to the Mass Graves layer using the unique ID for each mass grave and then using the Field Calculator, the distance field was added to the mass grave dataset as POIDst.

Adding Elevation Values

Using the SAGA add raster values to points algorithm, raster values from the Digital Elevation Map layer were sampled at the point locations of mass graves and for the roads, streets, waterways, selected points of interest, and possible towns which were identified as being closest to each mass grave. These layers were then joined to the mass graves layer and the elevation fields were added to the mass grave dataset as MGElev, RdElev, StElev, WWLElev, POIElev, and

\section{PosTwnElev.}

Calculating Difference in Elevation Between Mass Graves, Roads, Streets, Waterways, Selected Points of Interest, and Possible Towns

Using the field calculator, the elevation for matching roads, streets, waterways, selected points of interest, and possible towns were subtracted from the mass grave elevations and added to the mass graves dataset as fields MgEl-RdEl, MgEI-StEl, MgEI-WWLEI, MgEl-POIEI, MgEI-PTnEI.

Calculating Slope and Least Cost Path Values

Using the QGIS slope algorithm, the Digital Elevation Map layer was transformed to the Slope layer, representing the rate of change in elevation between adjacent pixels. Using the SAGA add raster values to points algorithm, the slope value for each mass grave was added as the MGSlope field. Using slope values, a least cost path calculation was performed using the GRASS 
Cost Distance Analysis:Least Cost Path algorithm. This algorithm calculated a path from the nearest road point to the mass grave by choosing the smallest aggregate total slope value between the points. The Least Cost Path layer was joined to the mass grave layer and the least cost path value was added using the field calculator as the LCPCost and LCPDist fields. As the LCPDist field was represented in degrees, it was then converted to meters using the QGIS export and add geometry columns algorithm and added to the Mass Graves layer as LCPDistM.

\section{Data Analysis}

A CSV file with all information gathered from QGIS was exported and used to perform statistical analysis in SPSS (29). Three statistical analyses were done on the data in SPSS: 1) Principal Component Analysis (PCA), 2) Discriminant Function Analysis (DFA), and 3) Descriptive Analysis. Before starting each analysis, normalization of the data was performed on variables using a Z-score transformation as stated in Annex 1 . This was done to ensure that PCA could be performed; the Z-score transformation or standard score, helped standardize the variables by transforming them by using the number of standard deviations each data point is away from the average of each group. Those mass graves containing less than 5 individuals recovered and those greater than 150 were removed from the data set. The removal of the mass graves with less than 5 individuals was based on the assumption that these were most likely ad-hoc burials done by the community after finding bodies (31). Mass graves with more than 150 individuals were ouliers and skewed the analysis, which was otherwise weighted toward graves containing 152 to 494 individuals. Additionally, a logistic regression was performed to identify whether mass graves could be predicted based on presence of individuals recovered among variables. This was not the 
case. However, variables that provided high variance inflection factors based on the logistic regression (VIF <2) were removed to avoid multicollinearity prior to performing PCA and DFA (Appendix 1) since PCA requires minimal correlation between variables. Descriptive analysis and Principal component analysis were performed using selected variables, as shown in Appendix 1.

\section{Results}

This study used graves exhumed by FAFG throughout the country. Most graves were concentrated in the central and northern areas of the country, as shown in Figure 3. The range of number of individuals recovered was $0-488$, however for over $51 \%$ of mass graves a single individual was recovered (Figure 4). This distribution appeared random, which was corroborated the PCA and DFA analyses.

$P C A$

The eigenvalues of the PCA were used to determine which variables (highest loading, both positive and negative) were driving variation and to identify patterns that could be hidden in the data. Based on the variables added to the PCA (Table 2), it appeared that those variables related to elevation had the strongest influence in explaining the first component. Additionally, the difference between the mass grave elevation and water way elevation also appeared to have a strong influence in explaining variance, meaning that mass graves were usually located at a higher elevation than waterways.

Some personal accounts narrated by survivors of such atrocities in Guatemala, relay that often they would find bodies near a river, drag them out, and bury them when they could (31), which could explain the change in elevation from waterways. In addition, it could also explain 
that mass graves are located further away from waterways, since there is less variance in the change of elevation from mass graves to possible towns. This is further supported by a higher variance explained in the variable 'distance to possible town' from 'mass grave location' provided by the second loading. The second principal component also provides information on road distance, which is seen to have a strong influence in the loadings and indicating it is a feature that may factor in determining where a mass grave is placed due to the variance explained in the first 2 loadings. PCA also suggested that the number of individuals recovered in a given grave has little influence in explaining the variance in grave location.

DFA

Discriminant Function Analysis revealed that a prediction of number of individuals recovered is not possible with the information available (Figure 5 and Table 3). Different groups with different numbers of individuals recovered were tested, however, the best separation among groups only provided a classification rate of $42.8 \%$ and a cross validation of $34.8 \%$ (Table 4 ).

\section{Descriptive Statistics}

Descriptive analysis helped to more clearly interpret the evidence from the PCA and DFA analyses. Ranges for variables that related to distances from mass graves were created and their percentages of frequencies were estimated (Table 5). Pie charts for each distance variable were created for easy visualization of their distribution (Figure 6). Additional pie charts were created for those variables with the difference of elevation from mass graves to different variables (Table 6 and Figure 7). 
From these results there is an evident pattern that most mass graves are located within a specific range of distances from roads. About $75 \%$ of mass graves are less than $1 \mathrm{~km}$ from the closest road, and the least cost path variable shows similar results. These two variables are related, with least cost path differentiating in a creating a path that decreases the aggregate slope change between mass grave and road. However, these two features were similar in distance; this was also seen visually in the QGIS project (Figure 8). Mass grave distances to streets are similar to road distances, however, there is a greater variability. Mass graves tend to be located in nonresidential areas, although near to concentrations of streets that may be closely related to Points of interest.

Forty-six percent of mass graves are within $1 \mathrm{~km}$ of a point of interest, but $34 \%$ of them are further than $5 \mathrm{~km}$, which is consistent with this variable having no significant predictive value. However, upon further visual examination in QGIS, it was observed that there were many points of interest clustered, indicating larger cities and some populated areas without any points of interest where they would be expected to be. This indicates that more complete data sources are needed and possibly explains the $34 \%$ of mass graves being further than $5 \mathrm{~km}$ for a point of interest.

Mass grave distance to waterway is one of the significant variables noted in the PCA analysis. The majority or close to $55 \%$ of mass graves are between $2 \mathrm{~km}$ and $5 \mathrm{~km}$ from a waterway. From this observation, it may be inferred that mass graves are most likely closer to other features and are not routinely placed near bodies of water. The low number of exceptions can also be explained based on the personal accounts of survivors, who buried bodies as they found them floating down the river. 
Variables representing changes in elevation between mass graves and roads, streets, points of interest, possible towns and waterways, show that most mass graves are located with minimal or no change in elevation. This indicates that there was an effort to minimize moving a body or bodies either up or down a slope relative to most variables. Based on the variables analyzed, if there was a change in elevation, there is no discernable inclination towards moving bodies either higher or lower. The exception is water; there appears to be a tendency for bodies to be moved higher, this can be attributed to the natural tendency of bodies of water to find the lowest stable elevation relative to the surrounding environment. However, it can also indicate that mass graves are generally not in proximity to bodies of water, as inferred from the distance to waterway information.

\section{Discussion}

Using open data sources and tools such as QGIS for this study proved to be very userfriendly. There are many tutorials available online for the explanation of all the plugins and algorithms used in this research. This is critical, as organizations or groups wanting to explore the use of this tool would have the support needed and will not feel intimidated. Additionally, using QGIS allowed for the manipulation and visualization of data to gain further insights.

The analytical process used resulted in very few features deemed statistically significant enough to be used for creating a predictive model. However, it provided essential information to be able to move forward in future studies. Distance from roads, waterways, potential towns, points of interest and changes in elevation relative to those features appears to show clear patterns and show that mass graves fall within specific distance from mass graves (Table 5 and 6). 
This indicates that efforts to conceal mass grave sites are minimized to the greatest extent possible. It thus appears that, at least in Guatemala, the principle of least effort expended superseded the imperative to camouflage the presence of a mass grave. More complex analyses of these features should be considered for future models.

Based on results, it is clear that the number of individuals buried is not correlated with the variables examined in this study; the distribution of mass grave size appears to be random relative to the variables analyzed. This is an important finding since it would be intuitive to assume that same size mass graves (e.g. the very large vs. the very small) would share a similar distribution pattern. Furthermore, it would be intuitive to consider that the disposal of a larger number of individuals would require more effort than a smaller number of individuals, thus leading to larger graves being placed closer to roads, with minimal change in elevation and even closer to towns and point of interest. However, the data show no such pattern.

The greatest limitations for this research were the lack of data easily available in open source formats and access to more detailed information on the individual mass graves. Information concerning the location and circumstances of the initial disappearances of those individuals recovered, the circumstances of the eventual discovery of the mass grave, the detailed physical characteristics of the mass grave sites (e.g. depth, vegetation, soil conditions, etc.), the identification of perpetrators associated with mass graves (specific army units, state vs. non-state actors, etc.) could prove to be the most critical information necessary for developing a working model. Therefore, analyses of the geographic characteristics of the locations were restricted to developing ranges of possible distances and changes in elevation between transportation networks and areas where digging a grave is feasible. 


\section{Testing the data}

Based on the information gathered in this analysis, a new project in QGIS was created. Distance to roads, waterways, possible town and points of interest layers were used, as the previous analysis based on frequency, DFA and PCA indicated them to be the most relevant. By using the buffer algorithm, new polygons were created that encompassed the area within a $75 \%$ range defined by the frequency percentages of roads, possible towns, and waterways (Table 7). Similarly, this was done for the Points of Interest layer, creating a buffer of $1 \mathrm{~km}$ of distance from each point of interest (Table 8).

Using the intersection algorithm, another new layer was created containing only the areas where three of the created (Road, Waterway, Possible Towns) buffers overlapped. The 320 mass grave locations not included in the initial analysis were then added to the project without any alterations; only location was added. Out of the 320 mass graves, only 176 mass graves (55\%) were within the intersection of three buffered layers (Figure 9). The total area of the buffer was $9,550 \mathrm{~km}^{2}$ compared to the total area of the country being $108,890 \mathrm{~km}^{2}$, thus reducing the area to be searched to only $9 \%$ of the total land mass of Guatemala.

The points of interest buffer (Figure 10) created, was evaluated separately from other three because, as previously stated, the layer was not a complete nationwide dataset and therefore had minimal intersections with the previously created buffer. However, the point of interest buffer is complementary as it was able to predict 44 additional mass graves, thus $69 \%$ of existing graves were within these boundaries. However this adjustment added an additional $1204.59 \mathrm{~km}^{2}$ to the area of interest, or 10\% of the total land mass of Guatemala (Figure 10 and Table 9). 
This model shows that even though it cannot be used to predict all mass graves and still covers a large portion of the country of interest, it can be used to narrow areas of focus for a physical or satellite image search, especially if it is paired with known information from the ground or where some may suspect there has been a conflict.

\section{Conclusion}

This study lays the foundation for a more detailed predictive model that can be created by exploring more complex analyses of the variables used for this project. Presently, this research can be used as a tool to look at an area of interest and narrow down locations for further investigation based on the features studied. This research also creates a path for further research using a similar methodology.

During the process of this research it was noted that other variables should be further investigated. However, in many cases, accurate and open source data was not accessible at the level of detail required for an analysis sufficient to improve the accuracy of the model. Examples of such features are soil information, which was available, but not detailed enough to be of use. Tree cover is another feature that could be explored, since it can provide insight to understand a pattern of concealment (in areas covered by vegetation) or easier burial in open areas without vegetation. Due to costs associated with obtaining commercial satellite imagery at a high enough resolution to ascertain this, such analysis would require a test of a narrower search area than the entire country. Another feature that might be explored is the correlation of population density in areas surrounding the mass graves to the mass grave location; however, in this case it was not possible since census data from the 80 's (32) was not easily accessible (the census bureau in 
Guatemala being stablished in 1985), and may not have accurately represented populations in smaller communities due to conflict in any event.

Additionally, future work could examine areas of high risk only, such as regions in a state of armed conflict or facing large influxes of refugees. Some of these models exist and have the potential to predict municipalities with high probabilities of mass graves based on media reports of violence (27). Future studies should also search for similar patterns that are present in other countries that have suffered social disturbances to determine if the patterns in this study are or are not unique to Guatemala.

The prediction of mass grave locations is still a challenging question and this study has shown that many factors contribute to the prediction of their placement. Additionally, the lack of available data and/or easily accessible data may be the biggest impediment to creating a better prediction than was accomplished here. However, the goal of deciphering the patterns involved in the concealment of mass graves is still worth pursuing to ensure that closure can be offered to families and communities. 


\section{References Cited}

1. Haglund, W.D., and Sorg, M. “Advances In Forensic Taphonomy: Method, Theory, And Archaeological Perspectives". Boca Raton, Fla.: CR. (2002). Print

2. Geber, J., and Geber, J. "Victims Of Ireland's Great Famine: The Bioarchaeology Of Mass Burials At Kilkenny Union Workhouse”. U Of Florida, 2015. Web.

3. Bellman, E. "Tsunami's Aftermath Has Survivors Coping With Rush Of Burials; Search For Missing Continues At Makeshift Morgues; No Money For Cremations". Wall Street Journal [New York, N.Y.] 2004: A.1. Web.

4. Huffschmid, A."Bones And Humanity. On Forensic Anthropology And Its Constitutive Power Facing Forced Disappearance". Athenea Digital 15.3 .(2015): 195-214. Web.

5. Klinkner, M. "Psycho-Social Aspects Surrounding Criminal Investigations Into Mass Graves”. International Criminal Law Review12.3. 2012: 409-26. Web.

6. Fletcher, L., and Weinstein, H. "Violence And Social Repair: Rethinking The Contribution Of Justice To Reconciliation." Human Rights Quarterly 24.3. (2002): 573-639. Web.

7. Huffschmid, A. "Huesos Y Humanidad. Antropología Forense Y Su Poder Constituyente Ante La Desaparición Forzada." Athenea Digital: Revista De Pensamiento E Investigación Social 15.3 (2015): 195-214. Web.

8. Haglund, W.D., and Sorg, M. H. “Advances In Forensic Taphonomy : Method, Theory, And Archaeological Perspectives”. Boca Raton, Fla.: CRC, (2002). Print.

9. Gassiot-Ballbé, E., and Steadman, D. "The Political, Social And Scientific Contexts Of Archaeological Investigations Of Mass Graves In Spain." Archaeologies 4.3 (2008): 429-44. Web.

10. A Firm And Lasting Peace And Progress In Fashioning A Region Of Peace, Freedom, Democracy And Development Dec. 29 1996, Https://Peaceaccords.Nd.Edu/Sites/Default/Files/Accords/Guatemala_1997_CPA_And_Annexes.Pdf,

11. Casallas, D.F., Padilla-Piedrahita, J., "Antropología Forense En El Conflicto Armado En El Contexto Latinoamericano. Estudio Comparativo Argentina, Guatemala, Perú Y Colombia". Universidad Nacional De Colombia, 2004. Maguaré 18: 293-310

12. Fuentes, C., Morales Santos,F., Villalobos, L.R., Ramírez, J.R.,"Guatemala, Memoria Del Silencio". Oficina De Servicios Para Proyectos De Las Naciones Unidas,Guatemala, Litoprint 1999.

13. Equipo Argentino de Antropologia Forense. EAAF (2020) http://eaaf.org/enobras/

14. Fundación De Antropología Forense De Guatemala . FAFG, 2018 Https://Fafg.Org/Desaparecidos/

15. Amnesty International. Https://Www.Amnestyusa.Org/About-Us/

16. International Committee Of The Red Cross. ICRC.2018 Https://Www.Icrc.Org/En/WarAnd-Law/Protected-Persons/Missing-Persons

17. USC Shoah Foundation, "The Guatemalan Genocide Testimony Collection"., Visual History Archive. 2019 Http://Sfi.Usc.Edu/Collections/Guatemalan

18. Kalacska, M.E., Lynne S.B., Sanchez-Azofeita, A., And Caelli, T.. "The Application Of Remote Sensing For Detecting Mass Graves: An Experimental Animal Case Study From Costa Rica." Journal Of Forensic Sciences 54.1 (2009): 159-66. Web. 
19. Ruffell, A., And Mckinley, J. “Forensic Geoscience: Applications Of Geology, Geomorphology And Geophysics To Criminal Investigations". Earth-Science Reviews, (2005)., 69(3-4), 235-247

20. Ruffell, A., And Mckinley, J. “Geoforensics”. Belfast, UK: John Wiley \& Sons Ltd, 2008

21. Snirer, E. "Hyperspectral Remote Sensing Of Individual Gravesites - Exploring The Effects Of Cadaver Decomposition On Vegetation And Soil Spectra." (P. 148). Master Of Science Thesis, Mcgill University., 2014. Web

22. Wilson, A.S., Janaway, R.C., Holland, A.D., Dodson, H.I., Baran, E., Pollard, A.M., \& Tobin, D.J. "Modelling The Buried Human Body Environment In Upland Climes Using Three Contrasting Field Sites". Forensic Science International, (2014). 169(1), 6-18

23. Congram, D.R. "Spatial Analysis And Predictive Modelling Of Clandestine Graves From Rearguard Repression Of The Spanish Civil War." Order No. NS23167 Simon Fraser University, Canada, (2010). Ann Arbor: Proquest. Web..

24. Dirkmaat, Dennis C. "Archaeology, Mass Graves, And Resolving Commingling Issues Through Spatial Analysis." A Companion To Forensic Anthropology. Chichester, UK: John Wiley \& Sons, 2012. 175-96. Web.

25. Congram, D.R., Kenyhercz, M., and Green, A.G. "Grave Mapping In Support Of The Search For Missing Persons In Conflict Contexts." Forensic Science International 278 (2017): 260-68. Web.

26. Arias, V.M. "Application Of GIS And Spatial Data Modeling To Archaeology: A Case Study In The American Southwest." Order No. 3601130 The University Of New Mexico, 2013. Ann Arbor: Proquest. Web..

27. HRDAG.," Modeling The Location Of Hidden Graves In Mexico"Https://Hrdag.Org/MxFosas.Html

28. QGIS Development Team (2019). QGIS Geographic Information System. Open Source Geospatial Foundation Project. Http://Qgis.Osgeo.Org.

29. IBM Corp. ( 2019). IBM SPSS Statistics for Macintosh Version 26.0. Armonk, NY: IBM Corp.

30. Giraldo, J., "Busqueda de Verdad y Justicia; Seis Experiencias en Posconflicto:, Bogota, Colombia; CINEP (2004) Print

31. FAFG., "Informe De La Fundación De Antropología Forénse De Guatemala; Cuatro. Casos Paradigmaticos Solicitados Por La Commission Para El Esclarecimiento Historico De Guatemala" Guatemala: Serviprensa C.A. (2000) Print.

32. Instituto Nacional de Estadistica- Guatemala. (2019) https://www.ine.gob.gt/ine/institucion/historia/ 
Figures and Charts

Table 1. Summary of Distribution of Investigation by FAFG

\begin{tabular}{|l|c|c|c|c|c|}
\hline Department & $\begin{array}{c}\text { Exhumations } \\
\text { carried out }\end{array}$ & $\begin{array}{c}\text { Missing Family } \\
\text { Cases }\end{array}$ & $\begin{array}{c}\text { Reported Vic- } \\
\text { tims }\end{array}$ & $\begin{array}{c}\text { Recovered In- } \\
\text { dividuals }\end{array}$ & $\begin{array}{c}\text { Identified Peo- } \\
\text { ple }\end{array}$ \\
\hline Total & 1,274 & 2,201 & 10,789 & 5,935 & 2,179 \\
\hline
\end{tabular}

\section{Mass Graves in Guatemala}

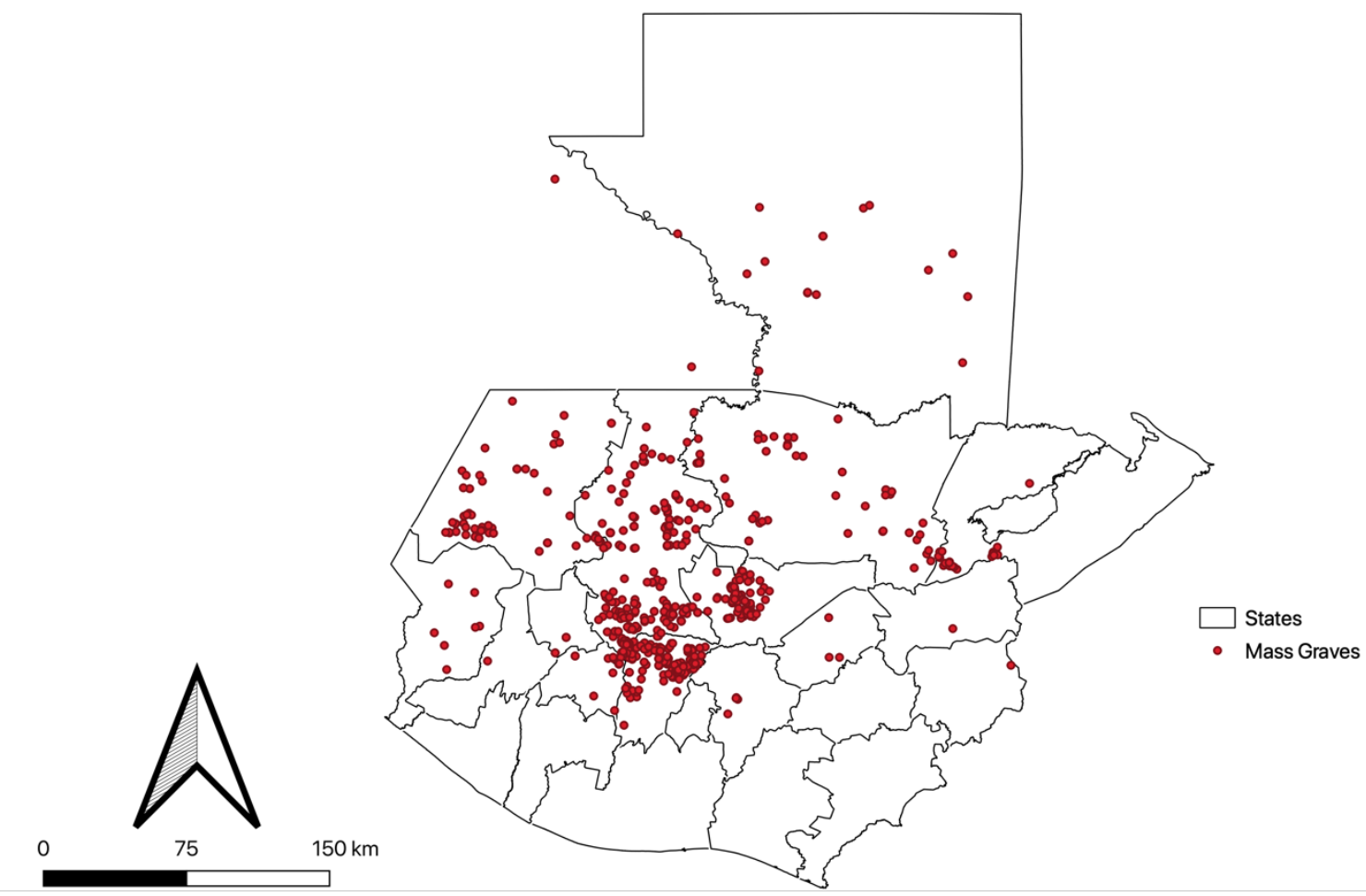

Figure 1. Map of Individual Mass graves in Guatemala 


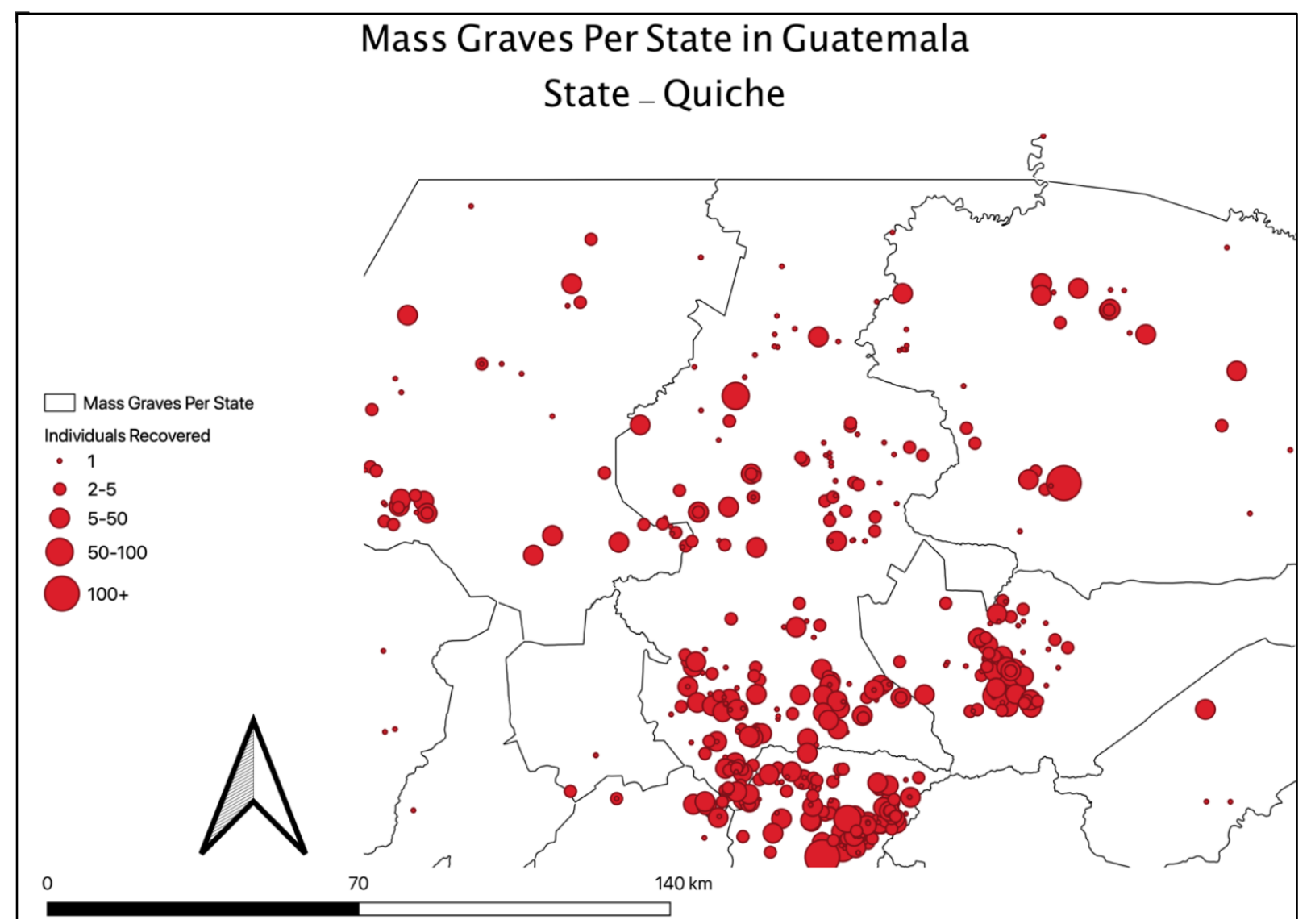

Figure 2. Map of the State of Quiche in Guatemala Showing Ranges of Individuals Recovered in Each Mass Graves. 


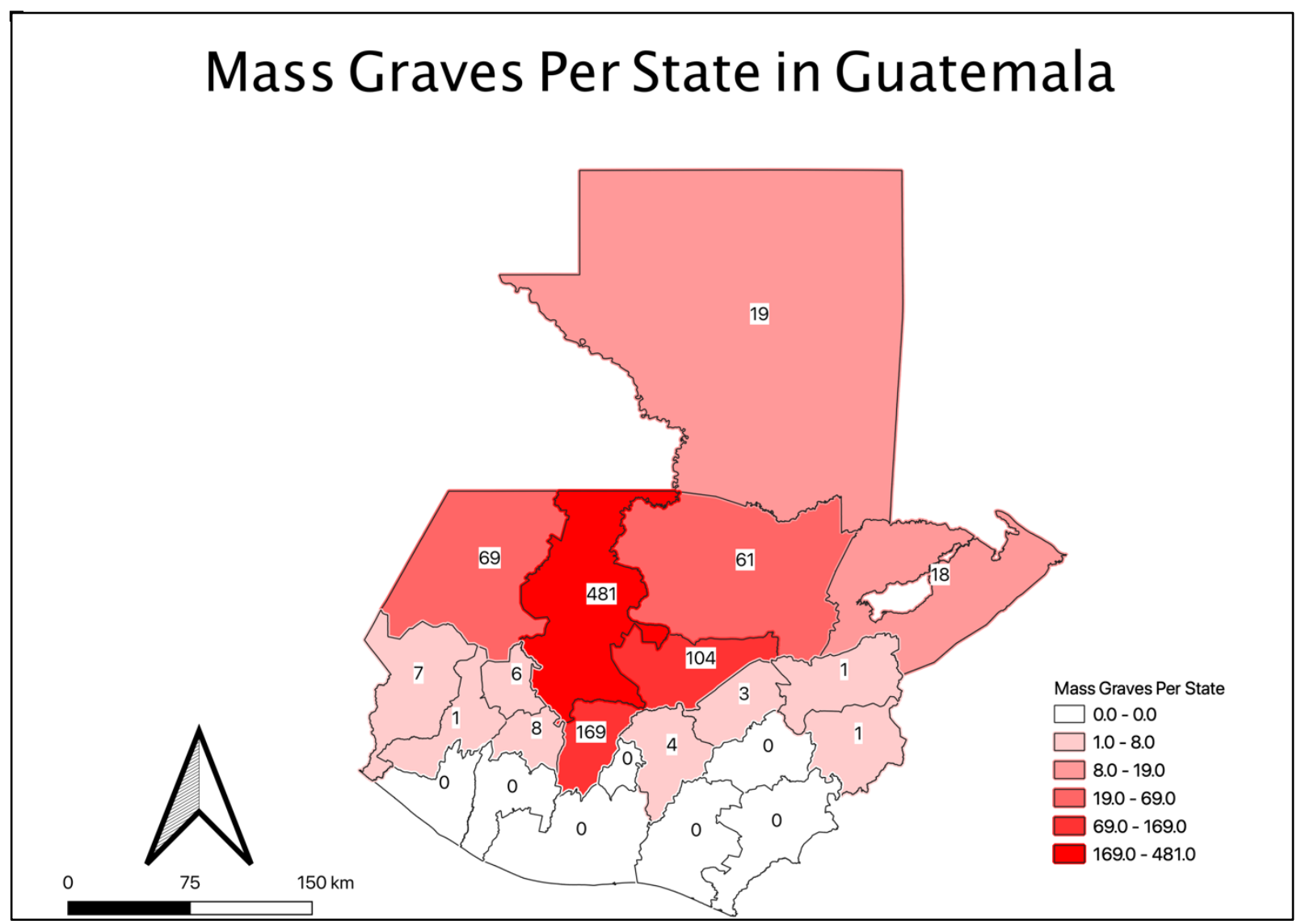

Figure 3. Summary of Mass Graves per State in Guatemala Used for Analysis

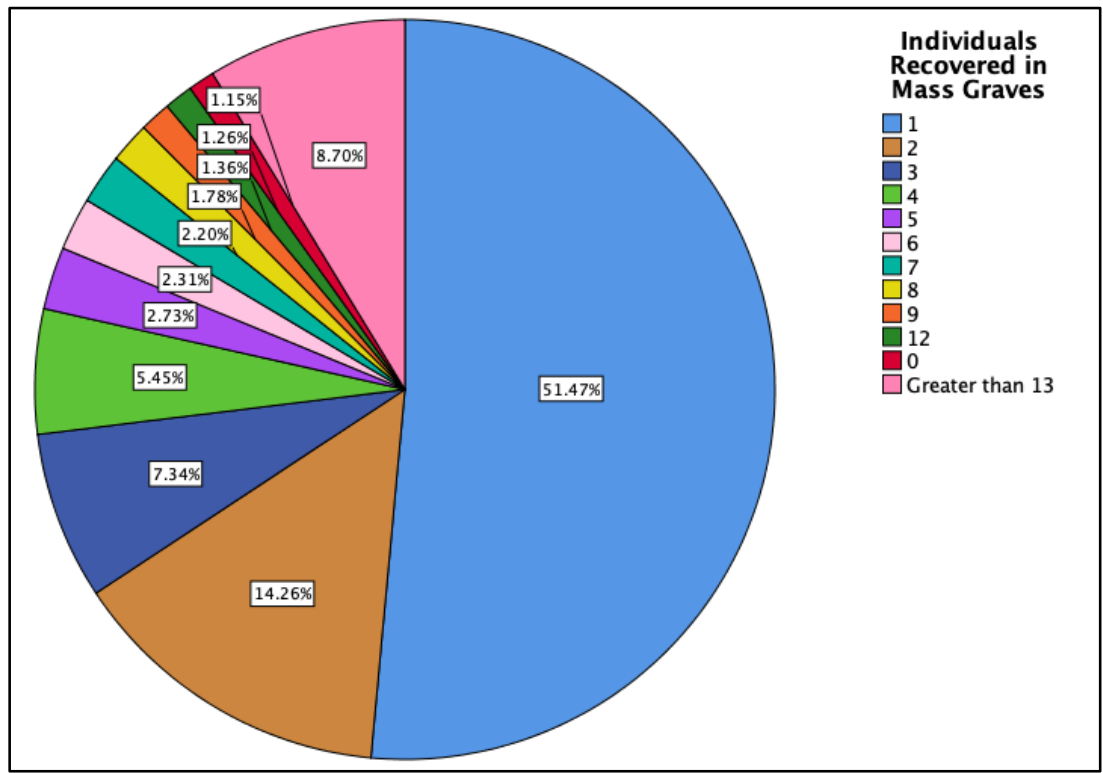

Figure 4. Frequency Percentage of Individuals Recovered in Mass Graves 
Table 2. Principal Component Analysis Result. Low Multicollinearity Variables Only

\begin{tabular}{|l|r|r|r|}
\hline \multicolumn{3}{|c|}{ Principal Component Analysis Component Matrix } \\
\hline \multicolumn{3}{|c|}{$65.94 \%$ Variance Explained in 3 Components } \\
\hline & Component \\
\cline { 2 - 4 } & 0.102 & -0.071 & 0.88 \\
\hline Number of Individual Recovered & 0.782 & -0.226 & -0.263 \\
\hline Mass Grave Elevation & -0.357 & 0.639 & -0.24 \\
\hline Road Distance & 0.327 & 0.385 & 0.442 \\
\hline Water Way Distance & -0.505 & 0.679 & 0.083 \\
\hline Possible Town Distance & 0.719 & 0.484 & -0.04 \\
\hline Mass Grave Elevation- Waterway Elevation & 0.496 & 0.567 & -0.089 \\
\hline Mass Grave Elevation-Possible Town Elevation & &
\end{tabular}

Table 3. Accompanying Structure Matrix for DFA Plot.

\begin{tabular}{|l|r|r|}
\hline \multicolumn{3}{|c|}{ Structure Matrix } \\
\hline \multicolumn{2}{|c|}{} \\
\cline { 2 - 3 } & 1 & 2 \\
\hline Road Distance & 0.581 & -0.372 \\
\hline Least Cost Path in Meters & 0.504 & -0.279 \\
\hline Waterway Distance & -0.292 & 0.259 \\
\hline Mass Grave Elevation-Possible Town Elevation & 0.201 & 0.128 \\
\hline Mass Grave Elevation- Waterway Elevation & -0.015 & 0.003 \\
\hline Possible Town Distance & 0.266 & -0.404 \\
\hline
\end{tabular}

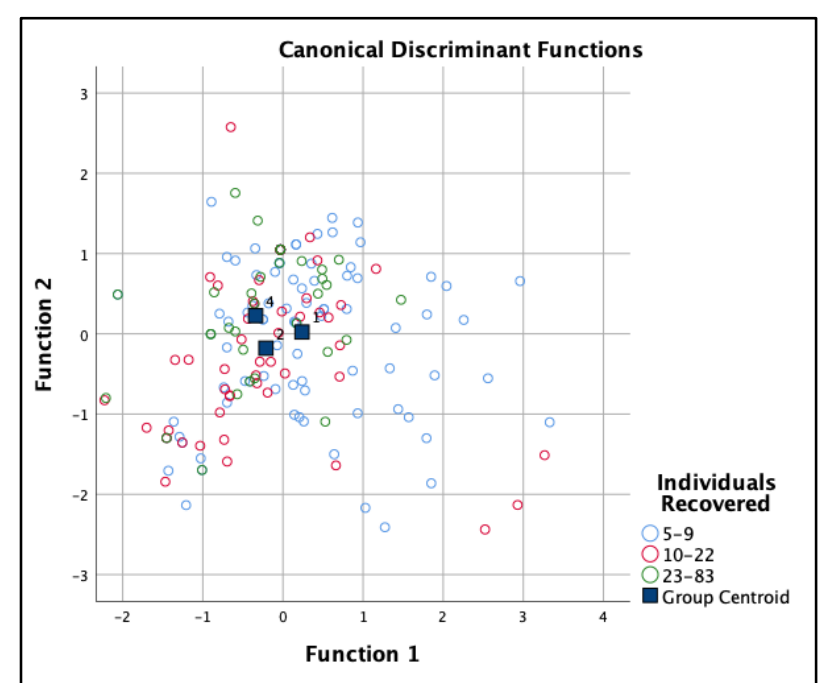

Figure 5. Discriminant Function Analysis (DFA) Showing Poor Classification Rate. 
Table 4. Accompanying Classification Results for DFA Plot

\begin{tabular}{|c|c|c|c|c|c|c|}
\hline \multicolumn{7}{|c|}{ Classification Results DFA } \\
\hline & & $\begin{array}{l}\text { Groups by } \\
\text { Individuals } \\
\text { Recovered }\end{array}$ & \multicolumn{3}{|c|}{$\begin{array}{l}\text { Predicted Group Member- } \\
\text { ship }\end{array}$} & \multirow[t]{2}{*}{ Total } \\
\hline & & & 1 & 2 & 4 & \\
\hline \multirow[t]{6}{*}{ Original } & Count & 1 & 39 & 24 & 35 & 98 \\
\hline & & 2 & 13 & 25 & 17 & 55 \\
\hline & & 4 & 11 & 7 & 16 & 34 \\
\hline & \multirow[t]{3}{*}{$\%$} & 1 & 39.8 & 24.5 & 35.7 & 100 \\
\hline & & 2 & 23.6 & 45.5 & 30.9 & 100 \\
\hline & & 4 & 32.4 & 20.6 & 47.1 & 100 \\
\hline \multirow[t]{6}{*}{$\begin{array}{l}\text { Cross-vali- } \\
\text { dated }\end{array}$} & Count & 1 & 37 & 26 & 35 & 98 \\
\hline & & 2 & 16 & 18 & 21 & 55 \\
\hline & & 4 & 11 & 13 & 10 & 34 \\
\hline & \multirow[t]{3}{*}{$\%$} & 1 & 37.8 & 26.5 & 35.7 & 100 \\
\hline & & 2 & 29.1 & 32.7 & 38.2 & 100 \\
\hline & & 4 & 32.4 & 38.2 & 29.4 & 100 \\
\hline
\end{tabular}




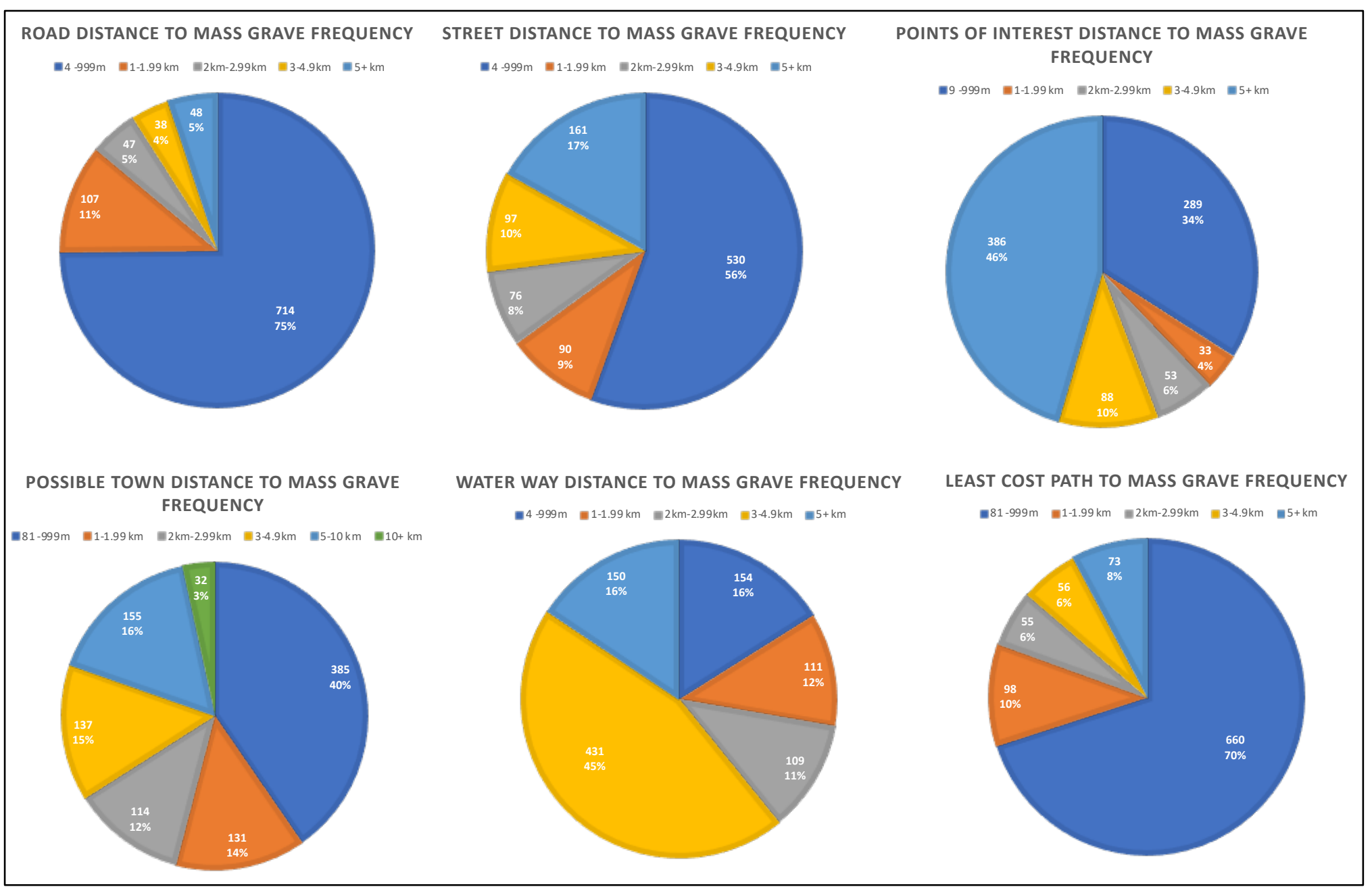

Figure 6.Pie Charts of Frequency Percentages of Distance from Mass Graves to Each Feature

Table 5.Summary Table of Descriptive Statistics of Features Related to Distance

\begin{tabular}{|c|c|c|c|c|c|c|c|c|c|c|c|c|}
\hline \multirow{2}{*}{ Ranges } & \multicolumn{2}{|c|}{ Road Distance } & \multicolumn{2}{|c|}{ Street Distance } & \multicolumn{2}{|c|}{$\begin{array}{c}\text { Points of Interest } \\
\text { Distance }\end{array}$} & \multicolumn{2}{|c|}{ Possible Town } & \multicolumn{2}{|c|}{ Water Way Distance } & \multicolumn{2}{|c|}{$\begin{array}{l}\text { Least Cost Path } \\
\text { Distance }\end{array}$} \\
\hline & Frequency & $\%$ & Frequency & $\%$ & $\begin{array}{l}\text { Fre- } \\
\text { quency }\end{array}$ & $\%$ & Frequency & $\%$ & Frequency & $\%$ & Frequency & $\%$ \\
\hline $0-999 m$ & 714 & $75 \%$ & 530 & $56 \%$ & 289 & $30 \%$ & 385 & $40 \%$ & 154 & $16 \%$ & 660 & $70 \%$ \\
\hline $1-1.99 \mathrm{~km}$ & 107 & $11 \%$ & 90 & $9 \%$ & 33 & $3 \%$ & 131 & $14 \%$ & 111 & $12 \%$ & 98 & $10 \%$ \\
\hline $2 \mathrm{~km}-2.99 \mathrm{~km}$ & 47 & $4 \%$ & 76 & $8 \%$ & 53 & $6 \%$ & 114 & $12 \%$ & 109 & $11 \%$ & 55 & $6 \%$ \\
\hline $3-4.9 \mathrm{~km}$ & 38 & $4 \%$ & 97 & $10 \%$ & 88 & $9 \%$ & 137 & $14 \%$ & 431 & $45 \%$ & 56 & $6 \%$ \\
\hline \multirow[t]{4}{*}{$5+\mathrm{km}$} & 48 & $5 \%$ & 161 & $17 \%$ & 386 & $40 \%$ & 187 & $19 \%$ & 150 & $16 \%$ & 73 & $8 \%$ \\
\hline & \multicolumn{2}{|l|}{$n=954$} & \multicolumn{2}{|l|}{$n=954$} & \multicolumn{2}{|l|}{$n=954$} & \multicolumn{2}{|l|}{$n=954$} & \multicolumn{2}{|l|}{$n=954$} & \multicolumn{2}{|l|}{$n=942$} \\
\hline & \multicolumn{2}{|c|}{$\operatorname{Min}=4.6134 \mathrm{~m}$} & \multicolumn{2}{|c|}{$\operatorname{Min}=8.7470 \mathrm{~m}$} & \multicolumn{2}{|c|}{$\operatorname{Min}=9.1385 \mathrm{~m}$} & \multicolumn{2}{|c|}{$\operatorname{Min}=81.31840 \mathrm{~m}$} & \multicolumn{2}{|c|}{ Min $=19.4996 \mathrm{~m}$} & \multicolumn{2}{|c|}{$\operatorname{Min}=4.61344 \mathrm{~m}$} \\
\hline & \multicolumn{2}{|c|}{$\operatorname{Max}=36762.13 \mathrm{~m}$} & \multicolumn{2}{|c|}{$\operatorname{Max}=26255.66 \mathrm{~m}$} & \multicolumn{2}{|c|}{ Max $=59388.11 \mathrm{~m}$} & \multicolumn{2}{|c|}{$M a x=26678.32 \mathrm{~m}$} & \multicolumn{2}{|c|}{$\operatorname{Max}=21492.99 \mathrm{~m}$} & \multicolumn{2}{|c|}{ Max $=58363.47 \mathrm{~m}$} \\
\hline
\end{tabular}




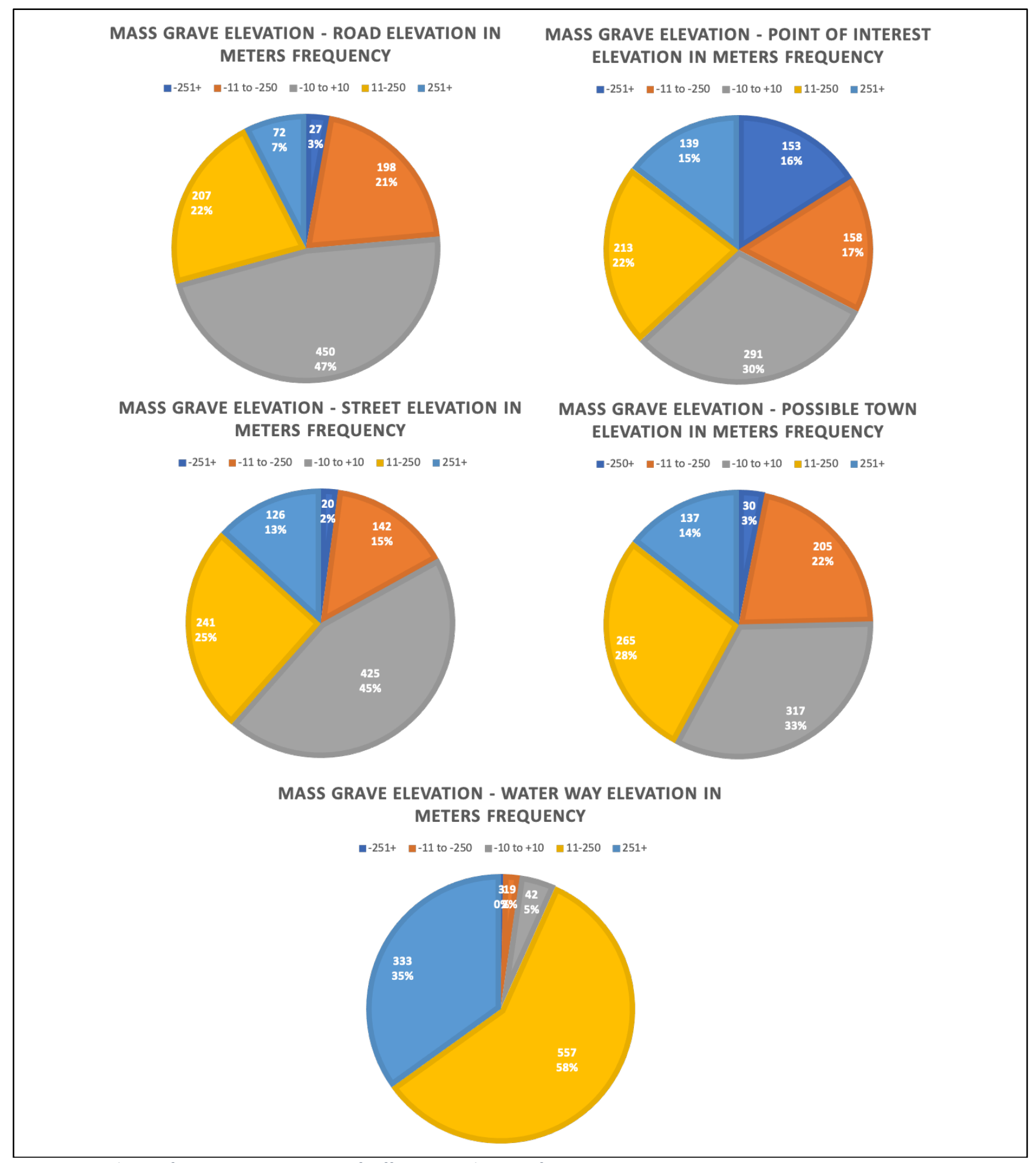

Figure 7. Pie Charts of Frequency Percentage of Difference in Elevation form Mass Grave Minus Feature. 
Table 6. Summary Table of Descriptive Frequencies of Difference in Elevation from Mass Grave to Feature.

\begin{tabular}{|c|c|c|c|c|c|c|c|c|c|c|}
\hline \multirow{2}{*}{ Ranges (m) } & \multicolumn{2}{|c|}{$\begin{array}{l}\text { Road Elevation in } \\
\text { meters }\end{array}$} & \multicolumn{2}{|c|}{$\begin{array}{l}\text { Street Elevation in me- } \\
\text { ters }\end{array}$} & \multicolumn{2}{|c|}{$\begin{array}{l}\text { Water Way Eleva- } \\
\text { tion in meters }\end{array}$} & \multicolumn{2}{|c|}{$\begin{array}{c}\text { Point of Interest Ele- } \\
\text { vation in meters }\end{array}$} & \multicolumn{2}{|c|}{$\begin{array}{c}\text { Possible Town Elevation } \\
\text { in meters }\end{array}$} \\
\hline & Frequency & $\%$ & Frequency & $\%$ & Frequency & $\%$ & Frequency & $\%$ & Frequency & $\%$ \\
\hline$-251+$ & 27 & $3 \%$ & 20 & $2 \%$ & 3 & $0 \%$ & 153 & $16 \%$ & 30 & $3 \%$ \\
\hline-11 to -250 & 198 & $21 \%$ & 142 & $15 \%$ & 19 & $2 \%$ & 158 & $17 \%$ & 205 & $21 \%$ \\
\hline-10 to +10 & 450 & $47 \%$ & 425 & $45 \%$ & 42 & $4 \%$ & 291 & $31 \%$ & 317 & $33 \%$ \\
\hline $11-250$ & 207 & $22 \%$ & 241 & $25 \%$ & 557 & $58 \%$ & 213 & $22 \%$ & 265 & $28 \%$ \\
\hline \multirow[t]{3}{*}{$251+$} & 72 & $8 \%$ & 126 & $13 \%$ & 333 & $35 \%$ & 139 & $15 \%$ & 137 & $14 \%$ \\
\hline & \multicolumn{2}{|l|}{$n=954$} & \multicolumn{2}{|l|}{$n=954$} & \multicolumn{2}{|l|}{$n=954$} & \multicolumn{2}{|l|}{$n=954$} & \multicolumn{2}{|l|}{$n=954$} \\
\hline & \multicolumn{2}{|c|}{$\begin{array}{l}\operatorname{Min}=-2787 \mathrm{~m} \\
\operatorname{Max}=2571 \mathrm{~m}\end{array}$} & \multicolumn{2}{|c|}{$\begin{array}{l}\operatorname{Min}=8.7470 \mathrm{~m} \\
\operatorname{Max}=26255.6642 \mathrm{~m}\end{array}$} & \multicolumn{2}{|c|}{$\begin{array}{l}\operatorname{Min}=9.1385 \mathrm{~m} \\
\operatorname{Max}=59388.1071 \mathrm{~m}\end{array}$} & \multicolumn{2}{|c|}{$\begin{array}{l}\text { Min }=81.31840 \mathrm{~m} \\
\operatorname{Max}=26678.31783 \mathrm{~m}\end{array}$} & \multicolumn{2}{|c|}{$\begin{array}{l}\operatorname{Min}=19.4996 \mathrm{~m} \\
\operatorname{Max}=21492.9911 \mathrm{~m}\end{array}$} \\
\hline
\end{tabular}

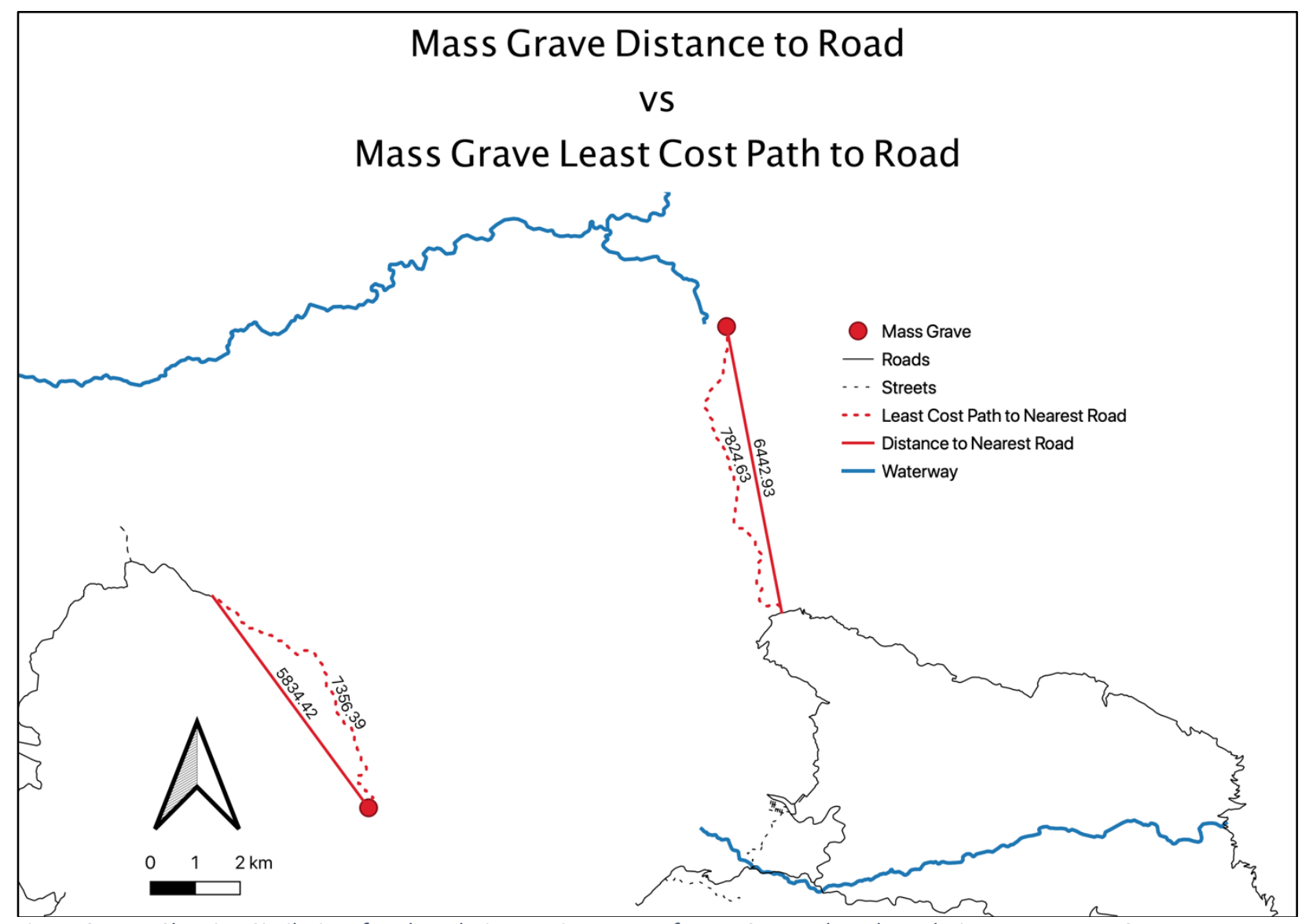

Figure 8. Map Showing Similarity of Path and Distance in meters of Least Cost Path and Road Distance to Mass Grave. 
Table 7. Summary of Features and Distances Used in Creation of Buffer. Buffers were Created Based on 75\% of The Frequencies from Results for Each Feature. Also included Area predicted for each buffer and Mass Graves Predicted.

\begin{tabular}{|l|l|c|c|c|}
\hline \multicolumn{2}{|c|}{ Buffer Features and Sizes } & \multicolumn{3}{c|}{ Buffer Prediction } \\
\hline \multicolumn{1}{|c|}{ Feature } & \multicolumn{1}{c|}{ Range of Distance } & $\begin{array}{c}\text { Area Predicted in } \\
\mathrm{km}^{\mathbf{2}}\end{array}$ & $\begin{array}{c}\text { Mass Graves Predicted } \\
\mathrm{N}\end{array}$ \\
\hline Road Distance & $0-1000 \mathrm{~m}$ & 47326.49 & 237 & $74 \%$ \\
\hline Waterway Distance & $2000-5000 \mathrm{~m}$ & 36055.23 & 176 & $55 \%$ \\
\hline Possible Town Distance & $0-4300 \mathrm{~m}$ & 53877.75 & 237 & $74 \%$ \\
\hline Combined Buffer & & $\mathbf{9 , 5 5 0 . 0 0}$ & $\mathbf{1 7 6}$ & $\mathbf{5 5 \%}$ \\
\hline
\end{tabular}

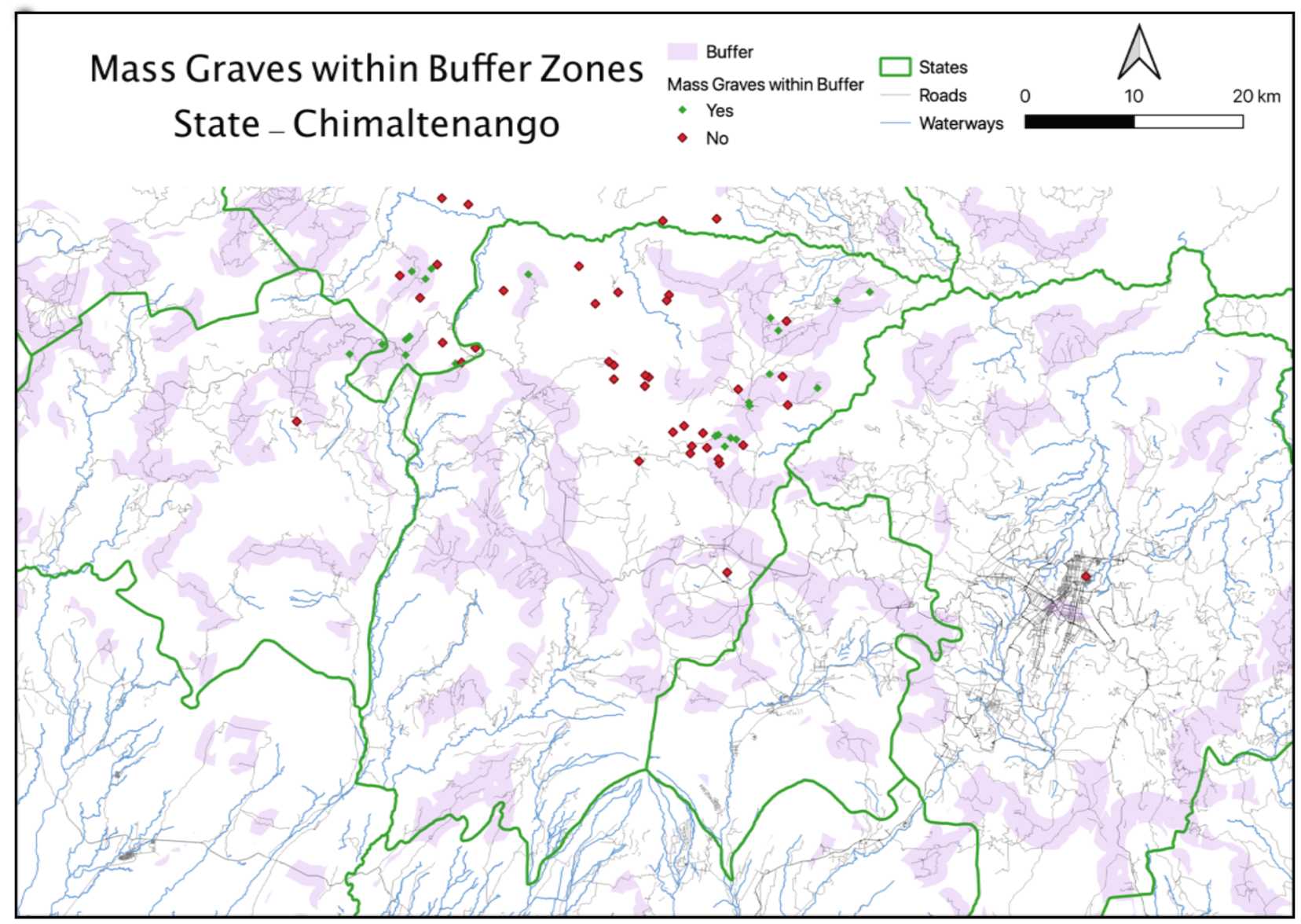

Figure 9. Map Showing Possible Areas of Interest to Further Investigate and Mass Graves not Used in Analysis. Fifty-five Percent (55\%) of Mass Graves Fall within Areas Shown in Frequencies. 


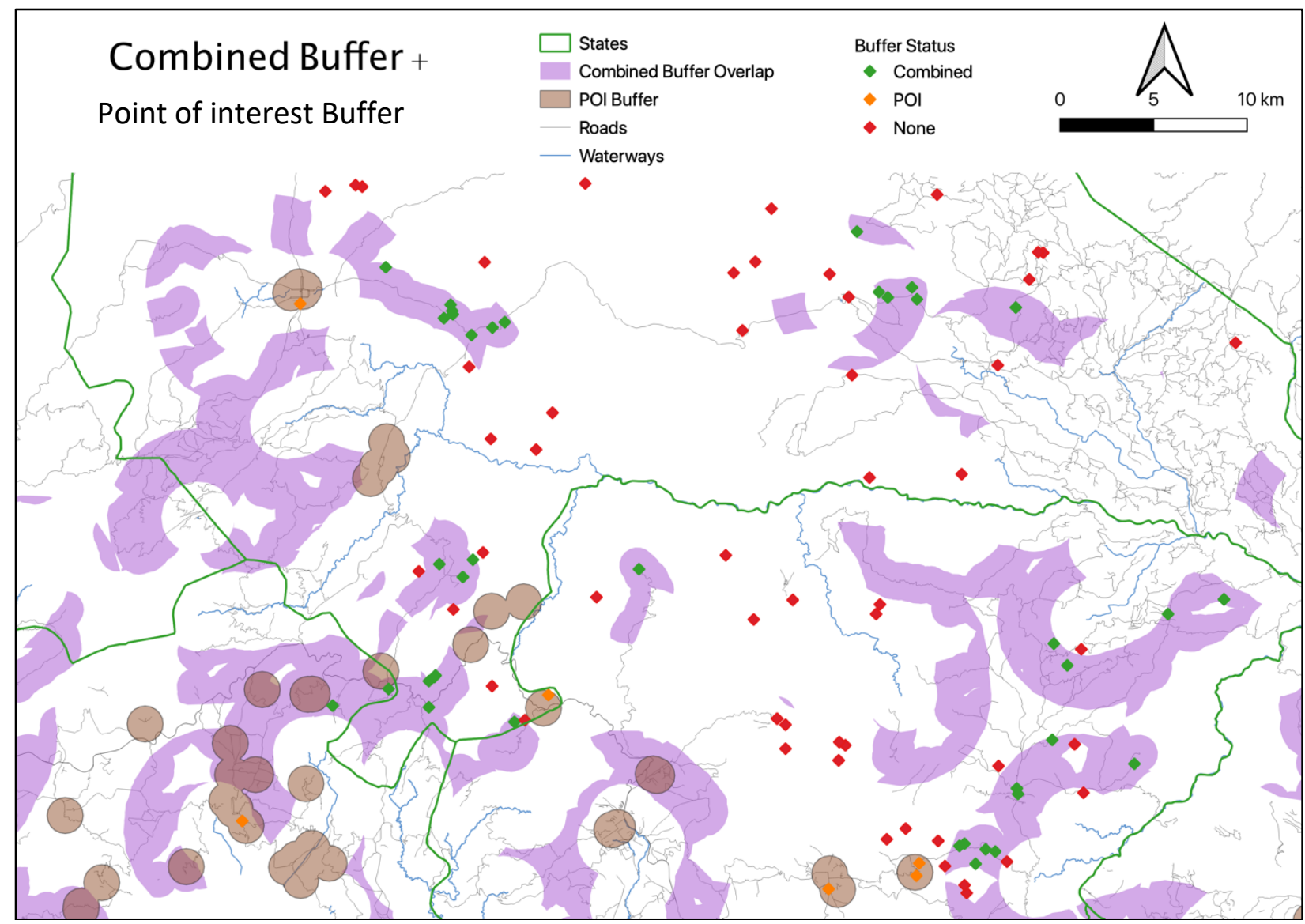

Figure 10. Map Showing Possible Areas of Interest to Further Investigate Using 2 Different Buffer Analysis. Points of Interest Buffer in Brown Shows a Complement to The Combined Buffer in Purple Including Roads, Waterways and Possible Towns. FortyFour Additional Mass Graves Fell Within the Brown Buffer.

Figure 11. Summary of Buffer for Points of Interest Including Distance Used, Area Predicted and Predicted Mass Graves.

\begin{tabular}{|c|l|c|c|}
\hline \multicolumn{2}{|c|}{ Point of Interest Buffer and Sizes } & \multicolumn{2}{c|}{ Buffer Prediction } \\
\hline Feature & Range of Distance & $\begin{array}{c}\text { Area Predicted in } \\
\mathrm{km}^{2}\end{array}$ & $\begin{array}{c}\text { Additional Mass Graves } \\
\text { Predicted }\end{array}$ \\
\hline Points of Interest & $0-1000 \mathrm{~m}$ & 1204.59 & 44 \\
\hline
\end{tabular}




\section{Appendix 1}

Data Dictionary - Variables/Features used and created and marked as used in each method

\begin{tabular}{|c|c|c|c|c|c|}
\hline Field Name & Description & Z-Score & PCA & DFA & $\begin{array}{l}\text { Descrip- } \\
\text { tive Sta- } \\
\text { tistics }\end{array}$ \\
\hline FIELD_2 & Unique number of mass grave investigation & & & & \\
\hline Depto. & State & & & & \\
\hline Muni. & Municipality & & & & \\
\hline L.P. & Town & & & & \\
\hline P.I. & People Identified & & & & \\
\hline I.R. & People Recovered & & $\checkmark$ & & \\
\hline V.R. & Victims Reported & & & & \\
\hline Lat & Latitude & & & & \\
\hline Long & Longitude & & & & \\
\hline IR Range & Individuals Recovered Range & & & & \\
\hline MGElev & Mass Grave Elevation & $\checkmark$ & $\checkmark$ & $\checkmark$ & \\
\hline RdUID & Road Unique Identifier & & & & \\
\hline RdElev & Road Elevation & & & & \\
\hline RdDist & Distance to Nearest Road & $\checkmark$ & $\checkmark$ & $\checkmark$ & $\checkmark$ \\
\hline StDist & Distance to Nearest Street & $\checkmark$ & & & $\checkmark$ \\
\hline StUID & Street Unique Identifier & & & & \\
\hline StElev & Street Elevation & & & & \\
\hline MgEl-RdEl & Mass Grave Elevation - Road Elevation & $\checkmark$ & & & $\checkmark$ \\
\hline MgEl-StEl & Mass Grave Elevation - Street Elevation & $\checkmark$ & & & $\checkmark$ \\
\hline WWLUID & Water Way Line Unique Identifier & & & & \\
\hline WWLElev & Water Way Line Elevation & & & & \\
\hline WWLDist & Distance to Nearest Water Way Line & $\checkmark$ & $\checkmark$ & $\checkmark$ & $\checkmark$ \\
\hline POIUID & Point of Interest Unique Identifier & & & & \\
\hline POIDist & Distance to Nearest Point of Interest & $\checkmark$ & & & $\checkmark$ \\
\hline POIElev & Point of Interest Elevation & & & & \\
\hline MgEl-WWLEI & $\begin{array}{l}\text { Mass Grave Elevation - Water Way Line Eleva- } \\
\text { tion }\end{array}$ & $\checkmark$ & $\checkmark$ & $\checkmark$ & $\checkmark$ \\
\hline MgEl-POIEI & $\begin{array}{l}\text { Mass Grave Elevation - Point of Interest Eleva- } \\
\text { tion }\end{array}$ & $\checkmark$ & & & $\checkmark$ \\
\hline F.Inv_Mon & Investigation Month & & & & \\
\hline F.In_Yr & Investigation Year & & & & \\
\hline F.Hec_Mnn & Estimated Date Month & & & & \\
\hline F.Hec_YR & Estimated Date Year & & & & \\
\hline Mun Code & Municipality Unique Identifier & & & & \\
\hline Total_Pop & Total Population of Municipality & & & & \\
\hline Pop_Urb & Total Urban Population of Municipality & & & & \\
\hline Pop Rural & Total Rural Population of Municipality & & & & \\
\hline PosTwnUID & Possible Town Unique Identifier & & & & \\
\hline PosTwnDst & Distance to Nearest Possible Town & $\checkmark$ & $\checkmark$ & $\checkmark$ & $\checkmark$ \\
\hline PosTwnElev & Possible Town Elevation & & & & \\
\hline MgEl-PTEl & $\begin{array}{l}\text { Mass Grave Elevation - Possible Town Eleva- } \\
\text { tion }\end{array}$ & $\checkmark$ & $\checkmark$ & $\checkmark$ & $\checkmark$ \\
\hline MG Slope & Mass Grave Slope & & & & \\
\hline LCPCoast & Least Cost Path from model & & & & \\
\hline LCPDistan & Least Cost Path distance meters & $\checkmark$ & & & \\
\hline Minicipios Pop Rural & Population Rural per municipality & & & & \\
\hline
\end{tabular}


Appendix 2

QGIS/GRASS/SAGA Algorithms Used

- QGIS Processing Toolbox

- GRASS - v.to.points

- QGIS distance to nearest hub (line to hub)

- GRASS Cost Distance Analysis:Least Cost Path

- SAGA add raster values to points

- QGIS export and add geometry columns

- QGIS minimum bounding geometry plugin

- SAGA polygon centroids

- QGIS DBSCAN clustering

- QGIS Buffer

- QGIS Intersection 


\section{Vita}

Perla Santillán was born on March 23, 1991, in the city of Matamoros, Tamaulipas, México. She graduated from Progreso High School, Progresso, Texas in 2009. She received her Bachelor of Arts in Biological Anthropology from the University of Texas at Austin in 2013. Subsequently she spent the next 5 years in employment with the American Red Cross, in different positions and states, working in disaster relief. She participated in over 25 disaster relief operations nationwide including Hurricane Maria in 2018, where she spent seven weeks helping in management positions. She later joined the VCU family to pursue a M.Sc. In Forensic Science with a concentration of physical evidence. During her time in VCU, Perla assisted Dr. Tall Simmons in forensic anthropological casework at the Virginia Office of the Chief Medical Examiner in both Richmond and Norfolk. Perla also claims to have the best dog in the universe named Kahlua, and an ok cat that thinks he's a dog named Pablo. 